\title{
IMPLEMENTASI KEBIJAKAN PENYELENGGARAAN KESEJAHTERAAN SOSIAL DI KOTA SUKABUMI: STUDI KASUS PEMBERDAYAAN WANITA RAWAN SOSIAL EKONOMI
}

\author{
${ }^{1}$ Rina Endah Sulistyowati, ${ }^{2}$ Ike Rachmawati, \& ${ }^{3}$ Dine Meigawati \\ ${ }^{1}$ Universitas Muhammadiyah Sukabumi \\ Email: rinaendah90@gmail.com \\ ${ }^{2}$ Universitas Muhammadiyah Sukabumi \\ Email: ike_rachmawatil@yahoo.com \\ ${ }^{3}$ Universitas Muhammadiyah Sukabumi \\ Email:dinemeigawati@gmail.com
}

\begin{abstract}
Abstrak
Tujuan Penelitian ini adalah untuk mengetahui implementasi kebijakan penyelenggaraan kesejahteraan sosial di Kota Sukabumi khususnya pemberdayaan wanita rawan sosial ekonomi. Penelitian ini menggunakan teori implementasi kebijakan yang dikemukakan oleh van Metter dan van Horn. Metode yang di gunakan dalam penelitian ini adalah metode kualitatif. Hasil dari penelitian menemukan bahwa implementasi kebijakan pemberdayaan sosial wanita rawan sosial ekonomi di Kota Sukabumi masih belum maksimal, karena ukuran dan kebijakan pada pelaksanaannya tidak sesuai dengan peraturan daerah provinsi, sumber daya finansial yang kurang mencukupi seluruh kegiatan, karakter agen pelaksana yang tidak tegas dalam menindak lanjuti kelompok usaha yang kurang berkembang, sikap pelaksana yang acuh terhadap keberlangsungan program kegiatan, dan komunikasi yang tidak dilakukan secara langsung antara pembuat kebijakan dan sasaran kebijakan.
\end{abstract}

Kata Kunci: implementasi kebijakan, kesejahteraan sosial, wanita rawan sosial ekonomi.

\begin{abstract}
The purpose of this study was to determine the implementation of social welfare implementation policies in the City of Sukabumi, especially the empowerment of women with socio-economic vulnerability. This study uses the theory of policy implementation proposed by van Metter and van Horn. The method used in this research is qualitative method. The results of the study found that the implementation of the social empowerment policy for women with socio-economic vulnerability in Sukabumi City was still not optimal, because the size and policies in the implementation were not in accordance with provincial regulations, insufficient financial resources for all activities, the character of the implementing agent was not firm in taking action follow up underdeveloped business groups, implementing attitudes that are indifferent to the sustainability of the activity program, and communication that is not done directly between policy makers and policy targets.
\end{abstract}

Keywords: policy implementation, social welfare, women with socioeconomic vulnerability. 


\section{A. PENDAHULUAN}

Menurut Kemensos RI (2005), Wanita Rawan Sosial Ekonomi (WRSE) adalah seorang wanita dewasa berusia 18-59 tahun dengan status menikah, belum menikah, bercerai atau janda yang ditinggal suami tanpa kejelasan, dan menjadi pencari nafkah utama keluarga yang tidak mempunyai penghasilan cukup untuk memehuhi kebutuhan sehari-hari karena faktor kemiskinannya, keterbelakangan dan kebodohannya mengalami gangguan fungsional dalam kehidupan sosial dan ekonominya sehingga yang bersangkutan mengalami kesulitan untuk menjalankan peranan sosial.

Wanita Rawan Sosial Ekonomi (WRSE) kebanyakan berasal dari keluarga yang kurang mampu dan seringkali mendapatkan pandangan negatif dari masyarakat sekitarnya. Mereka tidak diberikan kesempatan untuk mendapatkan hak yang sama karena diskriminasi dari orang lain, dan faktor- faktor lain seperti SARA (suku agama ras antar golongan). Data WRSE di Kota Sukabumi mengalami peningkatan dari tahun ke tahunnya, hal ini dapat dilihat pada tabel 1 sebagai berikut:

Tabel 1 Data WRSE di Kota Sukabumi

\begin{tabular}{ccc}
\hline No & Tahun & Jumlah (Orang) \\
\hline 1 & 2013 & 1,184 \\
2 & 2014 & 1,198 \\
3 & 2015 & 2,161 \\
4 & 2016 & 4,770 \\
5 & 2017 & 1,491 \\
\hline \multicolumn{2}{l}{ Sumber: } & Dinsos Kota Sukabumi 2019
\end{tabular}

Sumber: Dinsos Kota Sukabumi 2019

Dari tabel 1 di atas dapat di lihat bahwa jumlah data WRSE di Kota Sukabumi mengalami peningkatan dari tahun ke tahunnya. Namun terjadi penurunan pada tahun 2017 dari data awal 2016 dengan jumlah WRSE 4.770 orang menjadi 1.491 orang dikarenakan faktor diluar program Dinsos yaitu banyaknya WRSE yang tidak menjadi kepala keluarga lagi dalam artian wanita tersebut telah menikah lagi yang menjadikan suaminyalah yang menjadi kepala keluarga sebagai pencari nafkah dan adapun faktor lainnya yaitu banyaknya ibu rumah tangga yang berhasil berjuang (Survive) dengan keadaannya mereka dengan cara mendirikan usaha mandiri dengan modal pribadi, tetapi penurunan yang terjadi masih diatas jumlah data pada tahun 2013 yaitu 1.184 orang.

Dengan jumlah Wanita Rawan Sosial Ekonomi (WRSE) pada tahun 2017 Sebanyak 1.491 orang, Dinas Sosial sendiri dalam melaksanakan program penyelenggaraan 
kesejahteraan sosial memiliki 10 Kelompok Usaha Bersama (KUBE) yang terlahir dari gabungan wanita-wanita yang mendapatkan pelatihan keterampilan usaha yang dijadikan satu menjadi sebuah kelompok dengan tujuan agar memudahkan pencapaian tujuan yaitu meningkatkan kesejahteraan sosial secara efektif. Namun kenyataannya dari 10 KUBE yang ada hanya ada 2 KUBE saja yang masih berjalan hingga saat ini. Serta tidak adanya tindak lanjut dari Dinas Sosial sendiri sebagai pelaksana program untuk menindak lanjuti 8 KUBE yang tidak berjalan dengan seharusnya, dan dalam pelaksanaan program pelatihan keterampilan usahaanya pun dinas sosial hanya memiliki kuota peserta hanya $100 \mathrm{KK}$ setiap tahunnya, karena kurangnya dana dari pihak pemerintah sehingga belum bisa mencukupi semua kegiatan didalam program.

Penelitian ini bertujuan untuk mengetahui implementasi kebijakan penyelenggaraan kesejahteraan sosial di Kota Sukabumi, khususnya pemberdayaan wanita rawan sosial ekonomi atau WRSE.

\section{B. KAJIAN PUSTAKA}

\section{Implementasi Kebijakan}

Menurut Mustopadidjaja dalam Mulyadi (2016), istilah kebijakan digunakan dalam kegiatan pemerintah, serta prilaku negara pada umumnya dan kebijakan tersebut dituangkan dalam berbagai bentuk peraturan. Makna kebijakan sebagai serangkaian tindakan atau kegiatan sebagai upaya yang selalu berhubungan dengan usaha untuk mencapai beberapa maksud atau tujuan. Menurut Eulau \& Prewitt dalam Nugroho (2003), kebijakan adalah keputusan tetap yang dicirikan oleh konsistensi dan pengulangan (repetitiveness) tingkah laku dari mereka yang membuat dan dari mereka yang mematuhi keputsan tersebut.

Menurut Wahab dalam Arifin (2015), implementasi kebijakan merupakan pelakasanaan keputusan kebijakan dasar, biasanya dalam bentuk undang- undang, namun dapat pula berbentuk perintah-perintah atau keputusan-keputusan eksekutif yang penting atau keputusan badan peradilan lazimnya, keputusan tersebut mengidentifikasikan masalah yang diatasi, menyebutkan secara tegas tujuan/sasaran yang ingin dicapai, dan berbagai cara menstruktur/ mengatur proses implementasinya.

Ini berarti setelah suatu keputusan diambil, langkah berikutnya adalah bagaimana keputusan itu diimplementasikan. Implementasi bersifat interaktif dari proses kegiatan yang mendahuluinya. Ini berarti antara pengmbilan kebijakan dengan implementasinya memiliki 
keterikatan satu sama lain. Tanpa implementasi maka suatu kebijakan yang telah dirumuskan akan sia-sia belaka, karena itu implementasi kebijakan sebenarnya adalah action intervention itu sendiri. Hal ini menunjukkan bahwa implementasi kebijakan mempunyai kedudukan penting dalam pengambilan keputusan.

Sedangkan menurut Van Meter dan Horn dalam Agustino (2016), implementasi adalah tindakan-tindakan yang dilakukan baik oleh individu-individu atau pejabat-pejabat atau kelompok-kelompok pemerintah atau swasta yang diarahkan pada tercapainya tujuantujuan yang telah digariskan dalam keputusan kebijaksanaan.

\section{Model-Model Implementasi Kebijakan}

Model pendekatan top-down yang dirumuskan oleh Van Metter \& Van Horn dalam Agustino (2016), yang disebut dengan istilah A Model of The Policy Implementation. Proses implementasi ini merupakan sebuah abtraksi atau performasi dari suatu pelaksanaan kebijakan yang pada dasarnya secara sengaja dilakukan untuk meraih kinerja implementasi kebijakan publik yang tinggi yang berlangsung dalam hubungan dengan berbagai variabel. Model ini mengandaikan bahwa implementasi kebijakan berjalan secara linier dari keputusan politik yang tersedia, pelaksana, dan kinerja kebijakan publik.

Ada 6 variabel yang mempengaruhi kinerja implementasi kebijakan publik, yaitu: ukuran dan tujuan kebijakan, sumber daya, karakteristik agen pelaksana, sikap dan kecenderungan para pelaksana, komunikasi antar-organisasi dan aktifitas pelaksana, dan lingkungan ekonomi,sosial, dan politik

Selanjutnya model implementasi kebijakan menurut George C. Edward III dalam Agustino (2016) mengemukakan ada 4 variabel yang saling berhubungan satu sama lain yang mempengaruhi implementasi kebijakan yaitu komunikasi dan disposisi. Komunikasi sangat menentukan keberhasilan pencapaian tujuan dari implementasi kebijakan publik. Implementasi yang efektif terjadi apabila pembuat keputusan sudah mengetahui apa yang akan mereka kerjakan. Pengetahuan atas apa yang akan mereka kerjakan dapat berjalan apabila komunikasi berjalan dengan baik sehingga setiap keputusan kebijakan dan peraturan implementasi harus ditransmisikan (atau dikomunikasikan) pada bagian personalia yang tepat. Komunikasi juga diperlukan agar para pembuat keputusan dan para implementor akan semakin konsisten dalam melaksanakan kebijakan yang akan diterapakan dalam masyarakat. Disposisi atau sikap pelaksana kebijakan adalah faktor penting dalam pendekatan mengenai 
pelaksanaan suatu kebijakan publik. Disposisi juga mempengaruhi pelaksanaan suatu kebijakan agar berjalan efektif, maka para pelaksana kebijakan tidak hanya harus mengetahui apa yang akan dilakukan tetapi juga harus memeliki kemampuan untuk melaksanakannya, sehingga dalam praktiknya tidak terjadi bias.

Model implementasi menurut Merilee S. Grindle dalam Agustino (2016), pendekatannya dikenal dengan nama Implementation as A Political and Administrative Process. Menurut grindle keberhasilan suatu implementasi kebijakan publik dapat diukur dari pencapaian outcomes (yaitu tercapai atau tidaknya tujuan yang ingin diraih. Yang mana hal ini dapat dilihat dari dua hal yaitu dilihat dari prosesnya, dengan mempertanyakan apakah pelaksana kebijakan sesuai dengan yang ditentukan dan apakah tujuan kebijakan tercapai.

\section{Proses Kebijakan Publik}

Kebijakan publik lebih mudah dipahami jika dikaji tahap demi tahap. Inilah yang menjadikan kebijakan publik menjadi "penuh warna" dan kajian yang amat dinamis. Proses kebijakan publik antara lain:

a. Penyusunan Agenda

Agenda setting adalah sebuah fase dan proses yang sangat strategis dalam realitas kebijakan publik. Dalam proses inilah memiliki ruang untuk memaknai apa yang disebut sebagai masalah publik dan prioritas dalam agenda publik dipertarungkan. Jika sebuah isu berhasil mendapatkan status sebagai masalah publik, dan mendapatkan prioritas dalam agenda publik, maka isu tersebut berhak mendapatkan alokasi sumber daya publik yang lebih daripada isu lain.

b. Formulasi kebijakan

Masalah yang sudah masuk dalam agenda kebijakan kemudian dibahas oleh para pembuat kebijakan. Masalah-masalah tadi didefinisikan untuk kemudian dicari pemecahan masalah yang terbaik. Pemecahan masalah tersebut berasal dari berbagai alternatif atau pilihan kebijakan yang ada.

c. Adopsi/ Legitimasi Kebijakan

Tujuan legitimasi adalah untuk memberikan otorisasi pada proses dasar pemerintahan. Jika tindakan legitimasi dalam suatu masyarakat diatur oleh kedaulatan rakyat, warga negara akan mengikuti arahan pemerintah.

d. Penilaian/ Evaluasi Kebijakan 
Secara umum evaluasi kebijakan dapat dikatakan sebagai kegiatan yang menyangkut estimasi atau penilaian kebijakan yang mencakup substansi, implementasi dan dampak. Dalam hal ini , evaluasi dipandang sebagai suatu kegiatan fungsional. Artinya, evaluasi kebijakan tidak hanya dilakukan pada tahap akhir saja, melainkan dilakukan dalam seluruh proses kebijakan.

\section{Faktor Penentu Impelentasi Kebijakan}

Dalam perspektif lain, implementasi kebijakan dianggap tidak efektif apabila tujuan kebijakan tidak dapat dipenuhi, jika orang-orang tetap bertindak dengan cara yang tidak diinginkan oleh maksud kebijakan, jika subjek kebijakan tidak memakai cara yang ditentukan oleh kebijakan, ataupun jika subjek kebijakan berhenti mengerjakan apa yang ditentukan. Menurut Hamdi (2014) Ada beberapa hal yang mengakibatkan satu implementasi kebijakan dikatakan efektif atau tidak yaitu:

a. Respek Anggota Masyarakat pada Otoritas dan Kepuasan Pemerintah

b. Kesadaran untuk Menerima Kebijakan

c. Ada atau Tidaknya Sanksi Hukum

d. Kepentingan Pribadi atau Kelompok

e. Bertentangan dengan Sistem Nilai yang ada

f. Keanggotaan Seseorang atau Sekelompok Orang dalam Suatu Organisasi

g. Wujudnya Kepatuhan Selektif

h. Waktu

i. Sosialisasi

j. Koordinasi Antar-Lembaga atau Antar-Organisasi

\section{Pemberdayaan masyarakat}

Istilah pemberdayaan memiliki pengertian menurut konteks budaya dan politik. Oleh karena itu, makna pemberdayaan tidak mudah diterjemahkan ke dalam semua bahasa. Pengertianpemberdayaan sebenernya mencakup kekuatan sendiri, kemandirian, pilihan sendiri, kedaulatan hidup sesuai dengan nilai-nilai yang dianaut seseorang atau masyarakat, kapasitas untuk memperjuangkan hak, kemerdekaan, pembuatan keputusan sendiri, menjadi bebas, kebangkitan, dan kapabilitas. 
Menurut Ife dalam Martono (2016), mendefinisikan konsep pemberdayaan masyarakat sebagai proses menyiapkan masyarakat dengan berbagai sumber daya, kesempatan, pengetahuan dan keahlian untuk meningkatkan kapasitas diri masyarakat didalam menentukan masa depan mereka, serta berpartisipasi dan mempengaruhi kehidupan dalam komunitas masyarakat itu sendiri. Proses pemberdayaan pada intinya diajukan guna membantu klien memperoleh daya untuk mengambil keputusan dan menentukan tindakan yang akan dilakukan yang terkait dengan diri mereka, termasuk mengurangi efek hambatan pribadi dan sosial dalam melakukan tindakan. Hal ini dilakukan melalui peningkatan kemampuan dan rasa percaya diri untuk menggunakan daya yang dia miliki, antara lain melalui transfer daya dari lingkungannya.

\section{Wanita Rawan Sosial Ekonomi (WRSE)}

Menurut Kemensos RI (2005), Wanita Rawan Sosial Ekonomi (WRSE) adalah seorang wanita yang karena faktor kemiskinannya, keterbelakangan dan kebodohan mengalami gangguan fungsional dalam kehidupan sosial dan atau ekonominya sehingga yang bersangkutan mengalami kesulitan untuk menjalankan peranan sosialnya. Wanita Rawan Sosial Ekonomi (WRSE) kebanyakan berasal dari keluarga yang kurang mampu dan sering kali mendapatkan pandangan negative dari masyarakat sekitar. Mereka tidak diberikan kesempatan untuk mendapatkan hak yang sama karena diskriminasi dari orang lain, dan faktor-faktor seperti SARA (suku agama ras antar golongan) serta budaya paterilinialistik.

\section{METODE PENELITIAN}

Penelitian ini menggunakan teori implementasi kebijakan yang dikemukakan oleh van Metter dan van Horn (Agustino, 2016). Metode yang di gunakan dalam penelitian ini adalah metode penelitian kualitatif (Sugiyono, 2016). Data yang diperoleh menggunakan wawancara, observasi, dan dokumentasi. Teknik pengangambilan sampel dilakukan dengan menggunakan teknik purposive sampling. Informan dalam penelitian ini antara lain: Plt. Kepala Dinas Sosial Kota Sukabumi, Kepala Bidang Pemberdayaan Kesejahteraan Sosial, Pengurus Kelompok Usaha Bersama (KUBE), Relawan, Anggota KUBE atau Wanita Rawan Sosial Ekonomi. Prosedur pengujian keabsahan data dilakukan dengan triangulasi.

\section{HASIL DAN PEMBAHASAN}




\section{Ukuran dan Kebijakan}

Kebijakan ini tidak sesuai dengan landasan hukumnya yaitu Peraturan Daerah Provinsi Nomor 10 Tahun 2012 yang menyebutkan bahwa dalam pelaksanaan kebijakan pemberdayaan WRSE itu menurut pasal 24 dilakukan dengan cara pemberian motivasi terlebih dahulu agar para WRSE tersebut terdorong dan memiliki semangat lebih untuk merubah kehidupan mereka menjadi lebih baik lagi selanjutnya diberikan pelatihan vokasional/keterampilan sebagai jalan penghubung agar tujuan tersebut dapat tercapai karena jika hanya sebuah motivasi yang diberikan tanpa adanya pemberian caranya untuk mencapai tujuan tersebut akan menjadi sia-sia dan selanjutnya pemberian stimulan modal untuk mendukung pelatihan yang dilakukan agar pelatihan yang telah dilakukan dapat dijadikan usaha yang serius kedepannya. Seharusnya tahapan seperti itu yang disarankan oleh Peraturan Daerah Provinsi namun dalam pelaksanaanya tidak sesuai, pelaksanaan kebijakan pemberdayaan WRSE pada tahun 2017 langsung diberikan stimulan modal tanpa adanya pemberian motivasi dan pelatihan vokasioanal yang mengakkibatkan KUBE tersebut tidak memiliki arah dan tujuan akan diapakan uang stimulan modal yang diberikan.

Dan untuk target dari kebijakan inipun tidak tepat sasaran dilihat dari anggota KUBE ada yang berusia lanjut yang mengakibatkan tidak efektifnya dalam pelaksanna program usaha bersama karena seharusnya jika dilihat dari Peraturan daerah kriteria yang tergolong WRSE yaitu wanita usia produktif 19-45 tahun. Jika dari sasarannya tidak tepat seperti ini akan mengakibatkan pada pelaksanaan usahanya pun tidak efektif, dengan usia lanjut seperti itu pastinya tidak akan bisa berbuat banyak pada pelaksanaan produksi. maka tidak salah banyak yang KUBE yang mengalami kegagalan pada 2017.

\section{Sumber Daya}

Dari segi sumberdaya manusia sudah dikatakan baik karena SDM yang terlibat yaitu TKSK diberikan pelatihan khusus pendampingan yang dilakukan di kementerian sosial yang berada di lembang bandung, dengan tujuan saat pelaksanaan program para SDM yang terlibat dilapangan paham akan tugas pendampingan pada saat pelaksanaan kegiatan dalam upaya pemberdayaan WRSE.

Adapun permasalahnya yang dihadapi yaitu dari segi Sumber daya finansial yang tidak mencukupi untuk memberi pelatihan kepada seluruh penyandang masalah WRSE yang tercatat pada tahun 2017 ada sekitar 1491 orang yang artinya hanya kurang dari 15\% 
pertahunnya yang mengakibatkan tidak efektif dalam pencapaian tujuan karena keterbatasan anggaran pelaksana kegiatan pelatihan tidak bisa semua WRSE bisa diikut sertakan dalam program pemberdayaan WRSE dan dalam pelaksanaan program yang dilakukan pertahunnya pun tidak bisa pastikan program yang dilakukan kepada $100 \mathrm{KK}$ itu dapat dikatakan berhasil.

\section{Karakteristik Agen Pelaksana}

Karakteristik dari para pelaksana kebijakan yaitu Dinsos kurang tegas dalam tindak lanjut kepada KUBE yang tidak berjalan karena tindak lanjut kepada KUBE yang tidak berjalan harus sambil diiringi dengan pelaksanaan evaluasi namun kenyataanya hal tersebut menjadi kurang optimal karena adanya hambatan anggaran untuk kegiatan evaluasi yang mengakibatkan pada pelaksana evaluasi yaitu TKSK tidak dapat dilakukan yang mengakibatkan KUBE tersebut tidak berhasil. Selain tidak adanya anggaran evaluasi atau upah untuk para petugas yang ditugaskan mengevaluasi KUBE yang kurang berkembang, pengevaluasian harus juga didukung dengan anggaran untuk pemberian modal usaha lagi karena saat peneliti mencari informasi langsung ke lapangan ternyata uang awal yang 20 juta yang diberikan Pemerintah Provinsi sudah habis dijadikan usaha warung sembako sederhana yang kesehariannya tidak banyak yang membeli karena kurang lengkap dan adanya warung sembako yang lebih lengkap lagi tidak jauh dari warung KUBE yang mengakibatkan banyak masyarakat lebih memilih belanja ke tempat yang lebih lengkap, yang menjadikan usaha warung sembako tidak banyak menghasilkan uang setiap harinya.

Adapun masalah lainnya yaitu banyaknya KUBE yang ingin menjalankan usahanya sendiri yang menjadikan modal awal yang diberikan sudah tidak tersisa lagi. Jika dalam pemberian tindak lanjut kepada KUBE yang tidak berkembang hanya sekedar diberikan tambahan pengetahuan usaha saja tidak sambil diiringi oleh tambahan anggaran maka pelaksanaan evaluasi tidak akan menghasilkan apapun akan menjadi sia-sia. Hal yang menjadikan kurang tegasnya agen pelaksana dalam menindak lanjuti KUBE yang kurang berkembang yaitu tidak ada anggaran khusus untuk pemberian ketegasan keberlangsungan kelompok usaha bersama (KUBE), karena karakteristik agen pelaksana mempengaruhi keberhasilan suatu implementasi kebijakan. 


\section{Sikap dan Kecenderungan Para Pelaksana}

Sikap pelaksanaan sudah cukup baik dalam pelaksanaannya selalu berusaha semaksimal mungkin dilihat dari jawaban pada saat wawancara peneliti dengan para informan 1 sampai 4. Dan adanya dukungan yang diberikan Pemerintah Kota dengan memberikan tambahan stimulan modal KUBE yang berjalan dengan baik agar usahanya biar lebih berkembang lagi semua hal yang dilakukan Pemkot itu cukup menjelaskan bahwa sikap pelaksana kebijakan di Kota Sukabumi sudah cukup baik. Namun dari segi pengawasan dan bimbingan tidak berjalan sesuai aturan yang ada, yang seharusnya pengawasan dilakukan maksimal 2 tahun lamanya agar KUBE tersebut benar-benar berhasil dalam melakukan usahanya, namun karena keterbatasan anggaran hal itu tidak bisa dilakukan sesuai dengan ketentuan, hal ini yang mengakibatkan persentase KUBE yang berhasil itu kecil.

Pengawasan yang dilakukan secara terus menerus selama 2 tahun lamanya itu bertujuan agar berhasil suatu KUBE berkemungkinana berhasil itu besar sebelum kelompok usaha bersama dilepaskan dari pengawsan dan pembimbingan dan melanjutkan usahanya sendiri. Namun dari segi pelatihannya pun memang dari awal tidak ada karena langsung pada tahap pemberian modal maka apa yang harus diawasi pada tahap pemilihan usaha yang akan dilakukan KUBE pun pihak pelaksana tidak terlibat dalam pengambilan keputusan tersebut KUBE yang telah diberi stimulan modal diberi kebebasan akan melakukan usaha apa tanpa adanya arahan yang diberikan. Karena hal tersebut diatas yang menjadikan pengawasan dan bimbingan KUBE tidak dapat dilaksanakan karena tidak ada yang harus diawasi karena sejak awal sudah tidak ada pelatihan pangan yang dilanjutkan menjadi sebuah usaha.

\section{Komunikasi Antar Organisasi dan Aktivitas Pelaksana}

Komunikasi tidak dilakukan secara langsung antara Dinsos dan peserta pelatihan/KUBE karena banyaknya tugas lain yang harus dilakukan Dinas Sosial tetapi meskipun pihak Dinas tidak langsung turun kelapangan, namun tugas monitoring tersebut dilimpah tugaskan kepada TKSK yang telah di beri pelatihan sebagai pendamping di semua program kebijakan PMKS namun tugas TKSK juga bukan hanya mengurusi WRSE saja banyak tugas pendampingan lainnya yang harus dilakukan yang menjadikan tumpang tindih pekerjaan dan tanggung jawab. Karena hal itulah komunikasi menjadi tidak optimal yang mengakibatkan persoalan yang cukup serius dilapangan banyak KUBE yang mengalami 
kegagalan dalam pelaksanaannya karena mereka tidak bisa mencurahkan keluh kesah yang dialami selama usaha kepada pihak pelaksana kebijakan Dinas Sosial agar mendapatkan jalan keluarnya.

Adapun TKSK yang bertugas dilapangan mereka tidak bisa langsung memberikan arahan kepada KUBE karena status TKSK yang hanya relawan Dinas Sosial yang tidak memiliki wewenang dalam pengambilan keputusan, kalaupun ada masukan atau keinginan dari KUBE bisa disampaikan kepada TKSK dan TKSK baru menyampaikan ke pihak pelaksana kebijakan yaitu Dinas Sosial hal itu akan menjadi tidak efektif dalam pelaksanaannya. Jika komunikasi terjalin secara langsung dan baik maka kecil kemungkinan KUBE yang tidak berhasil pada tahun 2017.

\section{E. KESIMPULAN}

Hasil dari penelitian menemukan bahwa implementasi kebijakan pemberdayaan sosial (WRSE) masih belum maksimal, karena ukuran dan kebijakan pada pelaksanaannya tidak sesuai dengan peraturan daerah provinsi, sumber daya finansial yang kurang mencukupi seluruh kegiatan, karakter agen pelaksana yang tidak tegas dalam menindak lanjuti kelompok usaha yang kurang berkembang, sikap pelaksana yang acuh terhadap keberlangsungan program kegiatan, dan komunikasi yang tidak dilakukan secara langsung antara pembuat kebijakan dan sasaran kebijakan.

Dalam implementasi kebijakan pemberdayaan Wanita Rawan Sosial Ekonomi (WRSE) di Kota Sukabumi pada pelaksanaannya tidak sesuai dengan apa yang disebutkan di Peraturan Daerah Provinsi Nomor 10 tahun 2012. Sumber daya manusia yang terlibat dalam pelaksana program kebijakan yaitu relawan/TKSK sudah dikatakan baik karena diberikan pelatihan training pendamping yang dilakukan oleh kementrian sosial di lembang Bandung. Namun yang menjadi hambatan yaitu dari sumber daya finansial yang belum mencukupi seluruh kegiatan pemberdayaan WRSE sekota Sukabumi. Tercatat ada 1491 orang penyandang masalah WRSE di Kota Sukabumi tetapi yang mendapatkan pelatihan hanya 100 orang pertahunnya yang menjadikan pelaksanaanya menjadi tidak menyeluruh dan efektif.

Kurang tegasnya karakterisrtik pelaksana kebijakan dalam menindak lanjuti kelompok usaha bersama (KUBE) yang kurang berkembang dengan baik tidak adanya pemberian pendampingan lanjutan yang dilakukan oleh Dinas Sosial karena terhambat oleh anggaran untuk melakukan evaluasi kepada KUBE yang gagal. Sikap pelaksana sudah cukup baik 
dalam pelaksananya selalu berusaha semaksimal mungkin dalam melaksanakan program. Namun dari segi pengawasan tidak berjalan sesuai aturan, yang seharusnya pengawasan yang dilakukan oleh pendamping maksimal 2 tahun lamanya namun tidak dapat dilakukan karena keterbatasan anggaran. Komunikasi yang terjalin tidak langsung dilakukan antara pelaksana kebijakan dengan sasaran kebijakan karena banyaknya tugas yang dilakukan Dinas Sosial. Karena komunikasi tidak berjalan dengan seharusnya yang mengakibatkan persoalan yang cukup serius dilapangan banyak KUBE yang mengalami kesalahan pengertian karena kurangnya arahan yang diberikan kepada sasaran kebijakan.

\section{DAFTAR PUSTAKA}

Agustino, L. (2016). Dasar-Dasar Kebijakan Publik. Bandung: Alfabeta.

Arifin, T. (2015). Kebijakan Publik dan Transparansi Penyelenggaraan Pemerintah Daerah. Bandung: Alfabeta.

Fahrudin, A. (2012). Kesejahteraan Sosial Internasional. Bandung: Alfabeta

Hamdi, M. (2014). Kebijakan Publik. Bogor: Ghalia Indonesia

Indrajit, W. (2014). Pemberdayaan Masyarakat dan Pembanguunan. Malang: Intrans Publishing

Komariah, A. (2014). Metodologi Penelitian Kualitatif. Bandung: Alfabeta

Martono, N. (2016). Sosiologi Perubahan Sosial Perspektif Klasik, Modern, Posmodern, dan Poskolonial. Jakarta: PT Raja Grafindo Persada

Moleong, L. J. (2016). Metodologi Penelitian Kualitatif. Bandung: Remaja Rosdakarya

Mulyadi, D, dkk. (2016). Studi Kebijakan Publik dan Pelayanan Publik. Bandung: Alfabeta.

Nugroho, R. (2003). Kebijakan Publik Formulasi, Implementasi, dan Evaluasi. Jakarta: Elek Media Komputindo

Peraturan Daerah Provinsi Jawa Barat Nomor 10 Tahun 2012 Tentang Penyelenggaraan Kesejahteraan Sosial.

Peraturan Daerah Kota Sukabumi Nomor 6 Tahun 2016 tentang Penyelenggaraan Kesejahteraan Sosial.

Rachmawati, I. (2018). Pedoman Penulisan Ristik dan Skripsi. Sukabumi: Program Studi Administrasi Publik Fakultas Ilmu Administrasi dan Humaniora.

Satori, D., \& Komariah, A. (2009). Metodelogi Penelitian Kualitatif. Bandung: Alfabeta.

Sugiyono. (2015). Metode Penelitian Tindakan Komprehensif. Bandung: Alfabeta.

Sugiyono. (2016). Metode Penelitian Kuantitatif Kualitatif dan R\&D. Bandung: Alfabeta.

Sukidjo, S., Sihono, T., \& Mustofa, M. (2014). Pemberdayaan Kelompok Perempuan dalam Pengentasan Kemiskinan Berbasis Pengembangan Usaha Mikro. Jurnal Economia, 10(1), 1-10.

Undang-Undang Nomor 11 Tahun 2009 Tentang Kesejahteraan Sosial. 